\title{
Lessons Learnt: Support Interventions during a Blended Course for Teacher-Educators from Urban and Rural Settings
}

\author{
Juliet Stoltenkamp, Martha Kabaka, Norina Braaf \\ Centre for Innovative Educational \& Communication Technologies (CIECT), University of the Western Cape, \\ Cape Town, South Africa \\ Email: jstoltenkamp@uwc.ac.za, mkabaka@uwc.ac.za, nbraaf@uwc.ac.za
}

Received 3 April 2014; revised 30 April 2014; accepted 15 May 2014

Copyright (C) 2014 by authors and Scientific Research Publishing Inc. This work is licensed under the Creative Commons Attribution International License (CC BY). http://creativecommons.org/licenses/by/4.0/

\section{(c) (i) Open Access}

\section{Abstract}

This comparative case study research focused on the design and delivery of a blended Programme for professional working teacher-educators from both urban and rural settings. The overall purpose of the Programme was to enhance the educators' Information Communication Technologies (ICT) skills, with emphasis on eTools for supporting teaching-and-learning methodologies. Two groups of teacher-educators undertook the course as part of their Professional Development (PD). For the educators situated in the rural setting, the course was integrated into their Bachelor of Education (Honours) Degree Programme. A strong facilitation and support approach was maintained throughout the Programme to encourage self-directed learning. A case study approach was adopted to explore the experiences in the overall implementation and impact of the Programme. The research reflects on the findings which include: Programme design and structure; critical face-to-face interaction; access to resources impact time management; design a support structure for the monitoring and evaluation of the Programme; educators as self-directed learners; eTools enhance teaching-and-learning methodologies; and personal barriers which hinder Programme commitment.

\section{Keywords}

Comparative Study, eTools, Blended Learning, Extensive Support, Professional Development (PD), Support Interventions 


\section{Introduction}

The Centre for Innovative Educational and Communication Technologies (CIECT) at the University of the Western Cape (UWC) designed and developed a blended learning course for teacher-educators, namely: Designing an Instructional Event. The course is registered with the South African Quality Authority (SAQA) at a National Qualification Framework (NQF), Level 6. This research is based on 2 groups of teacher-educators from urban and rural school settings, who engaged in the Programme in 2012 and 2013, respectively. Thirty six (36) educators (Grades R-12) — from Christel House (private school) in the Western Cape Province; and twenty nine (29) Science secondary school teacher-educators-from different rural schools in the Eastern Cape Province. This group was part of the 2013 BEd Honours Programme, Faculty of Education at UWC.

Each group received training on ICT with specific focus on eTools. Such skills are relevant as there is still a need for innovative approaches to improve the capacity building of teacher-educators in South Africa. By the end of the Programme, each participant was expected to: 1) explain the current trends in eLearning and how they affect the teaching practice; 2) understand the educational philosophies that could inform the online teaching/ learning/instructional practices; 3) design a small online teaching/instructional event; 4) understand the need for good structuring of course content for blended learning; 5) select eTools for use in the instructional event according to their pedagogical values and underpinning; 6) understand the roles of an online facilitator and how they affect the learning process; and 7) become self-directed learners.

Before and during the Programme implementation, participants were made aware of the assessment criteria. Hence the teacher-educators were expected to plan, design and develop a small online teaching/instructional event; and also to actively participate in the different sessions (both the face-to-face and online phases).

This research focuses on the overall experiences in the implementation and impact of the Programme, which aimed to enhance the educators' Information Communication Technology (ICT) skills. Moreover, emphasis was placed on the application of eTools to support teaching-and-learning methodologies; and a strong facilitation and support approach which was maintained throughout the Programme to encourage self-directed learning.

\section{Related Literature}

\subsection{ICT's in South African Schools}

African government institutions are making efforts to ensure that technology for Teaching and learning is available at all levels of schooling, a major shift from dependence on support from donor-support, Non-Governmental Organisation, small-scale, and pilot projects, among other; governments in Africa are mainly the change agents (Glen \& Isaacs, 2007: p. 1; eLearning Africa, 2013). For example some governments "have begun to be more proactive in co-ordinating and leading the development of ICT infrastructure in school systems as their ICT policies and implementation plans have taken shape” (Glen \& Isaacs, 2007: p. 1). The South African E-education White Paper states that by 2013 every learner in both rural and urban settings (primary and secondary schools) — was expected to be ICT literate (Department of Education, 2004: p. 17). Such policies emphasise the provision of ICT infrastructure to both primary and secondary school levels. Furthermore it aims to bridge the digital divide nationally, thus also meeting the demands ICT global village (Evoh, 2007: p. 64; Oludolapo, 2010). However, there seems to be a worrisome situation according to recent research, which reflects on a case whereby only 4195 schools out of 24,453 schools were connected to the internet (i.e. 17\%) (ICT Africa, 2013).

If ICT's are implemented in the most marginalised schools and communities across Africa, it would lead to the much needed social-economic development; as education will become more reachable (Glen and Isaacs, 2007: p. 4; Otieno, 2007). The South African government has stated in the National Policy Framework for Teacher-Education and Development, that the main goal is to ensure that qualified educators are continuously reskilled and provided with the necessary Professional Development (PD) support. The reskilling processes should include relevant ICT skills and resources for learners and educators across South Africa (Steyn, 2010: pp. 212-213). PD courses in ICT for various target groups such as staff in Higher Education Institutions (HEIs) and the private sector have also been receiving attention across the globe. Hence, educators can benefit from continuous engagement in PD ICT skills courses, through a blended learning approach (Bath \& Bourke, 2011; Ifeoma \& Olusola.adu, 2013).

\subsection{Blended Learning Courses}

Blended learning also termed hybrid or mixed mode learning is a term that is constantly evolving, hence 
researchers have indicated a state of challenges due to limited “distinction between hybrid and blended courses”. Moreover different authors commonly agree that there are four commonly agreed definitions of blended courses: the application of both face-to-face and instructional technology in teaching; the use of various forms of technology such as CD-ROMs with web-based technology for teaching; the use of pedagogical approaches such as constructivism and behaviorism even in the absence of learning technologies; and the blend of instructional technology for the completion of specific tasks (cited by Driscoll, 2002 in Owston, Murphy, \& Lupshenyuk, 2008: pp. 201-202; Koller, Harvey, \& Magnotta, 2006).

The first blended learning approach is specifically of significance in education as participants are able to benefit from the opportunities provided in both the face-to-face and online environments. Hence, this interaction creates a state of balance in relation to the access of information and knowledge (Osguthorpe \& Graham, 2003: p. 228; Virginia Common Wealth University, n.d; Dziuban, Hartman, \& Moskal, 2004). During implementation of this blended learning approach, participants require critical support. Therefore, during the design, certain questions need to be posed: "How will students taking blended courses be supported? Will there be $24 \times 7$ help desk support?” (EDUCAUSE, Diaz, \& Strickland, 2009). Additionally, recent research conducted in an American High School, indicates that educators require support through blended courses, so as to meet the 21st-century skills in classrooms. The research states that, more focus should be placed on those teachers-educators who have no previous ICT skills (Pape, 2010).

\subsection{Intensive Design and Implementation Processes of Blended Course}

The design, development and implementation of a blended learning approach entail intensive processes. Research shows that this approach has recently received more attention than conventional face-to-face; or purely online learning (Precel, Eshet-Alkalai, \& Alberton, 2009). However, there seems to be a lack of research on establishing what blended learning approaches categorically entails, which could offer clarity around the standards for effective course design. Hence, blended learning approaches still lack "a coherent body of research that unequivocally demonstrates learning benefits over traditional modes of instruction” (Smythe, 2012: p. 1; Johnson and Marsh, 2013). Such observations indicate the need for serious planning of blended learning course, so as to enable easy implementation and delivery-avoiding the mere "flip" of the classroom (McGee, 2013). Other issues which require attention include: redesign to meet the identified needs of unique target groups; the design of activities which enable interaction whereby students are able to interact by sharing course content; and the provision of essential support. Therefore, an instructional and developmental approach that fails to pay attention to these issues at the planning stages may lead to challenges that may hinder both the facilitators and course participants (Rowley, Bunker, \& Cole, 2002). Following, this research explores the intensive experiences of the implementation of the blended Design Programme for educators through the following case study methodology.

\section{Method}

A case study methodology was adopted to retrieve findings related to the engagement of educators within the Programme: Designing an Instructional Event. These educators teach in schools situated in an urban and various rural settings, respectively: 36 educators from Christel House, a private secondary school in the Western Cape; and 29 Science educators from various schools in the Eastern Cape, Mthatha [St. James Senior Secondary School (SSS); Khanya Naledi Combined School; Ntukayi S.S.S; Nomaka Mbeki S.S.S; and Msobomvu S.S.S, among others]. The educators from Christel House represented various teaching disciplines, from Grades $\mathrm{R}$ to 12; whereas the educators in the Eastern Cape represented the discipline of Science. It should be noted that the 65 participants within this study were full-time working educators and represented a mix of 41 females and 24 males.

A Qualitative Research Design was adopted in which data was collected 1) firstly, by making use of three (3) different types of open-ended questionnaires, namely, prior-learner; state of school ICT; and an evaluation. These questionnaires broadly covered the following areas of: ICT skills/eSkills; competencies and attitudes; relevance of the face-to-face interactions; views related to group work; time management skills; access to ICT resources at the institutional and individual levels; and prior teachers’ Professional Development Programme. 2) Secondly, data was analysed from individual participants' submissions and engagement in online discussion forums. 3) Lastly, observations of presentations on the last day of the face-to-face phase, whereby all educators were expected to showcase the use of eTools for teaching-and-learning purposes. The following is a discussion 
on the factors which impacted the design, development and delivery of the Programme. These were further collated and categorised into main themes.

\section{Discussion}

The researchers firstly describe the overall design and structure of the blended learning Programme. Following, a detailed comparison of the main themes highlighted during the data analysis process is discussed: 1) Programme design and structure; 2) critical face-to-face interaction; 3) access to resources impact time management; 4) design a support structure for the monitoring and evaluation of the Programme; 5) educators as self-directed learners; 6) eTools enhance teaching-and-learning methodologies; and 7) personal barriers which hinder Programme commitment. Lastly, the researchers provides a comparative summary matrix framework of the factors which influenced the delivery of the blended learning Programme.

\subsection{Programme Design and Structure}

A scaffolding approach for working educators was adopted, in which the course was implemented in two (2) phases. The educators were expected to engage in a face-to-face training intervention; and four (4) weeks within an online environment. This approach enabled participants to complete related tasks, as they were motivated and guided through milestones. The guides were available through email, discussion forums, instructional manuals and multimedia (screencasts). This blended learning approach was beneficial, as the group of educators, specifically those in the rural settings, experienced grave challenges due to limited infrastructure (at times no internet available for an entire week). Furthermore, it should be noted that due to these challenges the Programme was redesigned, in this case, an additional face-to-face phase for the educators in the rural settings.

Notably, the educators situated in the urban setting, had the opportunity to engage in the face-to-face phasein a fully functional computer lab at UWC. They were also able to complete the milestones without major challenges. It is important that the design and structure of a blended learning Programme should continuously be revised and redesigned according the target group and context. The following themes highlight the experiences of the educators and facilitators as they progressed through the structured Programme.

\subsection{Critical Face-to-Face Interaction}

Seventy percent (70\%) of urban respondents indicated that the hands-on, supportive face-to-face phase is valuable and relevant, even though they had completed their milestones without major challenges. This was comparable, as only $24 \%$ of the responses from educators in the rural setting indicated that face-to-face interaction is always critical; especially when adult learners need clarification with regards to tasks and related milestones. On the other hand, during the face-to-face phases, the facilitators observed, the great demand for assistance by all (100\%) of the educators (both groups/settings) - as they engaged with the various eTools.

Research has provided numerous reasons as to why face-to-face interaction during learning is relevant, as it provides an opportunity for teacher and learner interaction, especially to seek clarity and share ideas (Bejerano, 2008). It is therefore critical to provide the necessary support during face-to-face interactions, as it minimises the situation whereby assumptions are made concerning adult learner needs. Moreover, there is a need for skilled human capacity in order to support intensive blended learning Programmes. The teacher or facilitators roles cannot be disputed in learning, they are expected to "encourage and motivate, guide and monitor progress, give feedback, boost confidence, and maintain motivation” (Marsh, 2012: p. 8).

\subsection{Access to Resources Impact Time Management}

It was noted that access to necessary resources affected participants from both settings either negatively or positively. It was found that $100 \%$ of the educators from the urban setting finalised their course milestones within the stipulated time-frames. However, it should be highlighted that none of the educators in the rural settings completed milestones in the stipulated time-frames, for example 16 participants did not respond to any of the discussion forum topics within the given time period. Most of these educators requested extended time-frames for the submission of tasks. Research indicates that the lack of relevant technology infrastructure is among barriers that hinder access to skills among students and educators (UNESCO Institute for Statistics, 2006; Hennessy \& Onguko, 2010). Following, the educators from the urban setting had access to a fully equipped computer lab 
and a technical support member at their place of work (school); and 50\% had access to personal internet connected computers at their homes. In contrast, the educators from the rural setting encountered major access challenges. Only 18 educators had access to the internet at home; only 6 had access to computer labs within their working environments; 9 had internet access at work; and 7 had digital projectors/interactive whiteboards. Moreover, none of these educators had access to a fully equipped lab facility at their respective schools.

It should be noted that educators who enroll for this Programme are expected to engage in some pre-reading; and bring along content related to their subject—matter and technical resources, such as smart phones, 3G cards, laptops and flash-drives. Most of the educators (90\%) from the rural setting did not bring along their personal resources. Furthermore, the training facility in the rural setting (a computer lab) was equipped with desktop computers. However it had no internet connectivity, as the facilitators were informed that the entire surrounding Mthatha area had no network access—due to the fact that the network cabling system was "stolen and Telkom is refusing to come out again, as it was the second time that the cables were removed". Following, the participants were shown how to access their online teaching events (basic structures) — via mobile devices. However, only 4 participants were willing to make use of their smart mobile phones to access the online environment, as it required that they make use of their own data bundles.

Failure to manage time properly may lead to the failure of a course (Sasson, 2008). However, ICT resources are a pillar to any successful adoption by both educators and students. Therefore institutions must ensure that all resources are available so as to enhance teaching and learning (Bingimlas, 2009).

\subsection{Design a Support Structure for the Monitoring and Evaluation of the Programme}

Both groups of educators were supported and monitored by the facilitators, throughout the Programme. A dedicated support structure is designed prior to the Programme delivery. For example, during the online phase, each facilitator is assigned to a number of participants to support, monitor and assess milestones. This support structure is critical as the CIECT team delivered this Programme parallel to the daily operations of UWC. The online phase of the Programme provided substantive support for the educators and this was enhanced with constant communication. The facilitators observed the need for extensive support for the educators in the rural setting, specifically in relation to the completion and submission of productions which required more advanced eSkills, namely, the creation and application of a picture collage and a digital story. Furthermore, this extensive support process included constant communication with educators via emails and discussion forums. These included the creation of instructional manuals with relevant text and graphics, by the facilitators, for the completion of the final prototype (the creation of a small online teaching event); and the related productions: 1 ) the structure and design of an online course divided into manageable mini-instruction sheets (12); 2) engaging in 2 main discussion forums which were further sub-divided into 11 sub-topics; 3 ) creation of a digital story and photo-collage.

Despite the design of an extensive support structure, the facilitators observed that the educators in the rural settings demonstrated a worrisome level of commitment and participation. For example: 1) Learning Pathway 2A (Creation and application of collages and digital stories) - only 64\% of participants responded to discussion topics and submitted related milestone tasks; 2) Learning Pathway 2B (Completion of final assessment task) $29 \%$ of participants did not respond and submit accordingly. Dedicated support structure are necessary in supporting blended learning Programmes, for example in UWC the CIECT team "is tasked with these responsibilities since it was established to provide a structure for the implementation of integrated, holistic support and development for the institution" (Stoltenkamp, Kies, \& Njenga, 2007: p. 146). Other writers also argue that blended learning is characterised by team work between course participants and support team (Bailey, Ellis, Schneider, \& Ark, 2013).

\subsection{Educators as Self-Directed Learners}

This research found that educators from the urban setting presented themselves as self-directed learners, i.e. in relation to the completion of guided milestone activities. Ninety nine (99\%) of these participants were selfmotivated to accomplish milestones as expected. Only 1 educator required an extension to complete the final submission, namely, the development of a prototype (a small online teaching event). On the contrary, the educators from the rural setting required more assistance in relation to completing milestones during the online phase of the Programme. Most of these educators, 57\%, required continuous encouragement and support during the online phase in order for them to meet the stipulated submission dates. This led to an extension of submission 
deadlines, however, despite the support and extension of date's research findings indicated that $31 \%$ did not manage to respond to discussion forums neither submit tasks on the online phase.

The design of the Programme as discussed in Section 4.1 indicates that learners, even though they are adult working professionals, still require structure and order-(a learning pathway, specifically milestone online mini-tasks) - to guide and facilitate the process of self-directed learning. Furthermore, the facilitators observed the need for basic ICT skills attainment by participants, prior to engagement in a more interactive blended learning Programmes. Likewise, research indicates that age barriers also impact ICT adoption, especially adult learners (Tedla, 2012).

\section{6. eTools Enhance Teaching-and-Learning Methodologies}

The 2 groups of educators expressed similar responses related to the application of eTools in their specific disciplines. These responses were deliberated within discussion forums; and the educators were expected to demonstrate their understanding and application of specific eTools during the presentation phase of the Programme. Visiting principles and sponsors were able to view these presentations on the last of day of the face-to-face phase. Some of the comparable responses retrieved from the discussion forums regarding the effective use of eTools within their specific disciplines included:

Educator feedback from urban setting:

"To supplement our high-touch teaching (chalk and talk and face to face in class) with a high-tech approach (eLearning tools via internet, etc.) will surely enhance teaching. Teaching should be beyond the walls of the classroom. The learners' intelligence should be measured by the skilled help of the educator. Hence to add more color and value but not substitute my teaching all together through examples like: Audacity, PowerPoint Presentation, Google Blogger, aTube Catcher, Picasa, Digital Photo Story and Wordle...”. Figure 1 is an example of Educator feedback from rural setting:

The educators' ability to apply such eTools in their teaching discipline is in line with the growing demands of education which requires the society, to take "advantage of computer technology for purposes of improving teaching and learning process”, Vinci and Cucchi (2007) cited in Stoltenkamp, Kabaka and Kies (2013).

\subsection{Personal Barriers Which Hinder Programme Commitment}

In relation to personal educator-level barriers, the facilitators observed, during the face-to-face phases that some teachers from both groups lacked the confidence to complete basic activities by themselves and would repeatedly seek assistance. Buabeng-Andoh (2012: p. 2) has written broadly on personal barriers as major "factors influencing teachers' adoption and integration of information and communication technology into teaching”. In addition, an educator even expressed resistance to the adoption of eTools for teaching-and-learning purposes. This resistance had been reported elsewhere previously, for example, Haydn (2009) indicates that at the University of East Anglia teachers attitudes had improved from previous "surveys several years ago which suggested that there were various forms of teacher resistance to ICT". This could have been a barrier which hindered personal commitment to the Programme and its related milestones.

Following this was linked to the concern by some educators that they did not have the personal time to commit to the PD Programme. In the prior-learner questionnaire, the majority of educators had committed $0-7$ hours per week for personal studies. However, the research indicates a commitment of only 2 - 4 hours per week. Research provides time constraints as one of the major causes of failure of adults learners' for "not being able to

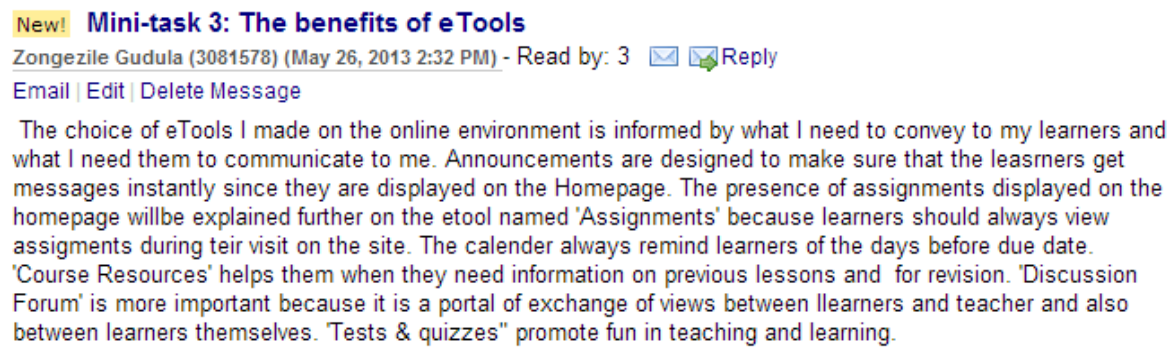

Figure 1. Educator feedback from rural setting (Retrieved from: ikamva.uwc.ac.za/portal/site (2014)). 
undertake learning (OECD, 2003: p. 5; Egenti \& Omoruyi, 2011). Furthermore, school-level-barriers, as indicated by the educators, also impacted personal commitment. In this case, educators in the urban setting, had access to the necessary infrastructure within their school environment. However, only 9 educators from the various rural school settings had access to technical support: 19 educators lacked resources such as digital projectors and interactive whiteboards; only 9 educators had computers for student use in their classrooms; and 13 educators had no desktop computers for student use within the school (e.g. a computer lab). Research provides time and access to necessary infrastructure as one of the critical barriers to ICT adoption for teaching and learning (Gay, 1997; Bingimlas, 2009).

Such barriers are not exceptional in the South African context, as research states that educators elsewhere face certain barriers in their efforts to adopt and integrate ICT in teaching and learning (Goktas, Yildirim, \& Yildirim, 2009; Sharma, 2003). Bingimlas (2009) has also written on these types of barriers faced by educators.

\subsection{Summary: Comparable Matrix Framework of the Overall Programme}

The matrix (Table 1) outlines a summary of the overall discussion, in relation to: resources, in relations to accessibility at each institutional level; just-in-time training tools; communication tools applied at each individual group; structure of each course to meet group needs; and human capacity that was employed on each group during facilitation of the Programme.

\section{Recommendations and Conclusion}

This comparative research paper has reflected on the engagement of two teacher-educator groups in a blended Design Programme. The overall purpose of the Programme was to enhance the educators' Information Communication Technology (ICT) skills, with emphasis on eTools to support teaching-and-learning methodologies.

Table 1. Comparable matrix framework of the overall programme.

INTENSIVE SUPPORT INTERVENTIONS EDUCATORS/RURAL SETTING I EDUCATORS/URBAN SETTING

\section{Internet Connectivity}

- During face-to-face training

- $\quad$ Online phase (access via home or school)

Just-in-time training tools

- Open source software

- Instructional manuals

Communication tools

- Email

- Telephone

- Discussion forum

\section{Design of support structure}

- Creation of a Learning Pathway with related milestone activities to assist with completion of Programme

Facilitation and support

- Facilitation/Co-facilitation
Limited internet access

Limited access (sometimes had to make use of mobile devices)

Stable internet connection

Access from schools/home

Packaged for personal use and to complete Packaged for personal use and to complete tasks

Instructional sheets (text and graphics)

attached to discussion topics - related to No instructional sheets provided milestone activities

Weekly communication to individuals (private) and group

Weekly communication to group

Educators called the office and facilitator's

mobile phones whenever they required Educators call the office during office hours assistance (including evenings, weekends - - whenever they required assistance. and a public holiday)

Two (2) online discussion forums with 11 One (1) online discussion forum with 4 sub-topics were developed in order to assist sub-topics were developed in order to assist the learners to complete all milestone the learners to complete all milestone activities activities

A Learning Pathway was created with two

main sections; and various mini-tasks— No Learning Pathway was required manageable chunks of learning

Need for intensive facilitation and support, Need for facilitation and support, mainly during the face-to-face and online phase during the face-to-face phase. 
Hence, the course was undertaken as part of their Professional Development (PD).

This research originated from two previous publications related to the Programme implementation and support structure. Following, this paper highlighted the following comparative areas 1) Programme design and structure; 2) critical face-to-face interaction; 3) access to resources impact time management; 4) design a support structure for the monitoring and evaluation of the Programme; 5) educators as self-directed learners; 6) eTools enhance teaching-and-learning methodologies; and 7) personal barriers which hinder Programme commitment.

The researchers recommend the adoption of this blended learning Programme, as one approach of meeting the goals of the South African White Paper on PD for teacher-educators, specifically ICT skills. Such blended learning Programmes afford full-time working professionals an opportunity to attain necessary skills.

Furthermore, the paper recommends the need for government and interested organisations (private sector and non-governmental organisations), to invest more in ICTs for educational purposes, especially within rural settings.

\section{Acknowledgements}

Researchers wish to acknowledge the CIECT team for their commitment in facilitating the Programme and providing all required information when requested.

\section{References}

Bailey, J., Ellis, S., Schneider, C., \& Ark, T. V. (2013). Blended Learning Implementation Guide. Version 1.0. http://net.educause.edu/ir/library/pdf/CSD6190.pdf

Bath, D., \& Bourke, G. (2011). The Blending of Blended Learning: An Experiential Approach to Academic Staff Development. http://www.ascilite.org.au/conferences/hobart11/downloads/papers/Bath-concise.pdf

Bejerano, A. (2008). Face-to-Face or Online Instruction? Face-to-Face Is Better. http://www.natcom.org/CommCurrentsArticle.aspx?id=884

Bingimlas, K. A. (2009). Barriers to the Successful Integration of ICT in Teaching and Learning: A Review of Literature. Eurosia Journal of Matematics, Science and Technology Education, 5, 235-245.

Buabeng-Andoh, C. (2012). Factors Influencing Teachers' Adoption and Integration of Information and Communication Technology into Teaching: A Review of the Literature. International Journal of Education and Development using Information and Communication Technology (IJEDICT), 8, 136-155.

Department of Education (DoE), South Africa (2004). Draft White Paper on e-Education: Transforming Learning and Teaching through ICT. Pretoria.

Dziuban, C., Hartman, J., Moskal, P., Sorg, S., \& Truman, B. (2004). Three ALN Modalities: An Institutional Perspective. In J. Bourne, \& J. C. Moore (Eds.), Elements of Quality Online Education: Into the Mainstream (pp. 127-148). Needham, MA: Sloan Center for Online Education.

EDUCAUSE, Diaz, V., \& Strickland, J. (2009). EDUCAUSE Learning Initiatives, Unit 7: Implementing Blended Learning. http://net.educause.edu/ir/library/pdf/ELI80077.pdf

Egenti, M. N., \& Omoruyi, F. E. O. (2011). Challenges of Women Participation in Continuing Higher Education Programme: Implications for Adult Women Counseling and Education. African Journals Online, 4.

eLearning Africa Report (2013). The eLearning Africa Report.

http://www.elearning-africa.com/media_library_publications_ela_report_2013.php

Evoh, C. J. (2007). Policy Networks and the Transformation of Secondary Education through ICTs in Africa: The Prospects and Challenges of the NEPAD e-Schools Initiative. International Journal of Education and Development using Information and Communication Technology (IJEDICT), 3, 64-84.

Gay, S. M. (1997). Teaching with Technology: A Case Study of Teachers' Perceptions of Implementing Computers into the Classroom. Unpublished Dissertation.

Glen, F., \& Isaacs, I. (2007). Survey of ICT and Education in Africa; ICT and Education Series. An InfoDev Research Project. http://www.infodev.org/infodev-files/resource/InfodevDocuments_353.pdf

Goktas, Y., Yildirim, S., \& Yildirim, Z. (2009). Main Barriers and Possible Enablers of ICTs Integration into Pre-Service Teacher Education Programs. Educational Technology \& Society, 12, 193-204.

Haydn, T. (2009). Teacher Education and ICT: Some Points for Consideration from the UK (pp 1-4). http://www.oecd.org/edu/ceri/41674026.pdf

Hennessy, S., \& Onguko, B. (2010). Developing the Use of Information and Communication Technology to Enhance Teaching and Learning in East African Schools: Review of the Literature. http://www.educ.cam.ac.uk/centres/cce/publications/CCE Report1 LitRevJune0210.pdf 
ICT Africa (2013). Only 17\% of Schools in South Africa Are Connected. http://www.ictafrica.info/FullNews.php?id=10585.

Ifeoma, E. R., \& Olusola.adu. E. (2013). The Teachers and the Use of ICT for Professional Development. http://ictforafrica.org/attachments/section/4/ict4africa2013_submission_34.pdf

Ikamva.uwc.ac.za. (2014). Design an Online Course: Discussion Forum. https://ikamva.uwc.ac.za/portal/site/1431d707-8a50-4d45-94b5-1cf04fe35214/page/b58602d1-0855-49f0-998b-c0ee5f465 $\underline{\mathrm{d} 26}$

Johnson, C., \& Marsh, D. (2013). The Laureate English Program Taking a Research Informed Approach to Blended Learning. Higher Learning Research Communications, 3. http://journals.sfu.ca/liu/index.php/HLRC/article/viewFile/103/96

Koller, V., Harvey, S., \& Magnotta, M. (2006). Technology-Based Learning Strategies. Social Policy Research Associates Inc. http://www.doleta.gov/reports/papers/TBL_Paper_FINAL.pdf

Marsh, D. (2012). Blended Learning Creating Learning Opportunities for Language Learners. New York: Cambridge University Press.

McGee, P. (2013). Looking for the Pedagogy in Blended Course Design. http://www.educause.edu/library/resources/looking-pedagogy-blended-course-design

OECD (Organisation for Economic Corporation and Development) (2003). Beyond Rhetoric: Adult Learning Policies and Practices. Report. http://www.edra.gr/pdf/9103011E-OECD.pdf

Oludolapo, O. O. (2010). Bridging the Digital Divide and the Impact of New Media Technologies on Development in South Africa. In S. Soomro (Ed.), New Achievements in Technology Education and Development (460 pages hard copy). University Campus Europe: In Tech Publishers.

Osguthorpe, R. T., \& Graham, C. R. (2003). Blended Learning Environments: Definitions and Directions. The Quarterly Review of Distance Education, 4, 227-233.

Otieno, S. (2007). Africa: Call to Equip African Teachers With ICT Skills. http://allafrica.com/stories/200706010157.html

Owston, R. D., Sinclair, M., \& Wideman, H. (2008). Blended Learning for Professional Development: An Evaluation of a Program for Middle School Mathematics and Science Teachers. Teachers College Record, 110, 1033-1064.

Pape, L. (2010). Blended Teaching \& Learning. The School Administrator, 67. http://www.aasa.org/SchoolAdministratorArticle.aspx?id=12924

Precel, K., Eshet-Alkalai, Y., \& Alberton, Y. (2009). Pedagogical and Design Aspects of a Blended Learning Course. International Review of Research in Open \& Distance Learning, 10.

Rowley, K., Bunker, E., \& Cole, D. (2002). Designing the Right Blend Combining Online and Onsite Training for Optimal Results. Performance Improvement, 41, 26-36. http://dx.doi.org/10.1002/pfi.4140410406

Sasson, R. (2008). Importance of Time Management. http://www.successconsciousness.com/blog/time-management/importance-of-time-management/

Sharma, R. (2003). Barriers in Using Technology for Education in Developing Countries. IEEE0-7803-7724-9103. Singapore Schools' Computers \& Education, 41, 49-63.

Smythe, M. (2012). Toward a Framework for Evaluating Blended Learning. Oscilite 25-28 November. http://www.ascilite.org.au/conferences/wellington12/2012/images/custom/smythe,_michael___toward.pdf

Steyn, G. M. (2010). Educators' Perceptions of Continuing Professional Development for Teachers in South Africa: A Qualitative Study. Africa Education Review, 7, 156-179.

Stoltenkamp, J., Kabaka, M., \& Kies, C. (2013). Course for Educators: Designing an Instructional Event Centre for Innovation and Communication Technologies (CIECT) University of the Western Cape. Proceedings of EDULEARN13 Conference, Barcelona, 1-3 July 2013, 1645-1655.

Stoltenkamp, J., Kies, C., \& Njenga, J. (2007). Institutionalising the eLearning Division at the University of the Western Cape (UWC): Lessons Learnt. International Journal of Education and Development using Information and Communication Technology (IJEDICT), 3, 143-152.

Tedla, B. A. (2012). Understanding the Importance, Impacts and Barriers of ICT on Teaching and Learning in East African Countries. International Journal for e-Learning Security (IJeLS), 2, 199-207.

UNESCO Institute for Statistics (2006). ICTs and Education Indicators: (Suggested Core Indicators Based on Meta-Analysis of Selected International School Surveys).

http://www.itu.int/en/ITU-D/Statistics/Documents/partnership/ICT_Education_Paper_Nov_2006.pdf

Virginia Common Wealth University (n.d). Online Teaching and Learning Resource Guide. Center for Teaching Excellence. http://www.vcu.edu/cte/resources/OTLRG/01_06_BlendedClasses.html 


\section{Appendix: Three (3) Questionnaires}

\section{1: Prior-Learner Profile Questionnaire (Educators Were Expected to Complete Questionnaire before Engaging in the Course)}

\section{Designing an Instructional/Online Teaching Event: Learner Profile \\ Dear Participant,}

It is important that we are equipped with some analytical information about you as you will be expected to engage within online and offline environments for the Designing an Online Teaching Event Course. Your commitment to complete the following information regarding Access to resources; Resource and time management; Skills/eskills, competencies and attitudes and Team work will enable facilitators and coordinators to collate a comprehensive analysis.

Personal Details

Please state your Name and Surname and which school you are affiliated with?

\section{What is your highest qualification?}

\section{Access to Resources}

\section{I currently have:}
A. a computer at home with internet access.
B. a computer at home with internet access.
C. a computer at home with no internet access.
D. no computer at home with no internet access.

\section{Resource and Time Management}

2. I would classify myself as someone who...
A. is always ahead of schedule.
B. needs reminders to get things done before the deadline.
C. procrastinates, often putting things off until the last minute.

3. How much time do you have available for independent study (including the week end)?
A. 0 - 3 hours a week.
B. 4 - 7 hours a week.
C. 8 or more hours a week.

Skills/eSkills, Competencies and Attitudes

4. How would you rate your reading skills?
A. Very good. I do a lot of reading.
B. Fair. I do it when I have to.
C. Poor. I don't like reading.

5. How would you rate your Word Processing Skills?
A. Poor. I rarely use a word processor.
B. Fair. I am able to use a word processor.
C. Good. I often use a word processor.

6. Solving a computer difficulty
A. Easily, I have the skills or the resources to fix most problems.
B. Moderately. I could probably find someone to help fix most problems.
C. Not at all. I have very little technical knowledge or the resources to help.

7. Can you copy/paste between different documents and applications?
A. No problem!
B. I think so. I'll ask someone to help.
C. I don't know.

8. How important is face-to-face interaction with you when communicating with someone?
A. Very important.
B. Not that important.

9. Do you know how to save files and upload attachments? 

A. No, not at all.
B. I think I could do it.
C. Yes, easily.

10. What are your expectations of the course?

...More experience wrt on-line education

\section{Team Work}

\section{Learner type}
A. I like to work independently on projects and assignments.
B. I like to listen to lectures and take notes.
C. I like to learn in groups with other students.

12. Are you willing to actively engage with others during workshops (face-to-face/ online)?
A. I do not spend a lot of time with colleagues on a course. I prefer to do my work.
B. I generally find it interesting to find out about the work and perspectives of other colleagues.
C. I don't mind talking with colleagues who ask me questions.

13. When writing to express yourself, you find it:
A. Easy. I love to write about my work, experiences and opinions.
B. Fairly easy. I don't mind writing.
C. Difficult. I do not like to express myself in writing.

\section{School ICT Capacity Questionnaire}

\section{Dear Participant,}

It is important that we are equipped with some analytical information on the state of ICT you're your school. Your commitment to complete the following information regarding Access to resources will enable facilitators and coordinators to collate a comprehensive analysis.

We thank you for taking your time to answer this survey. Your comments are very important and will be treated with confidentiality.

1. Your Schools Information and Communications Technology (ICT) capacity

Please indicate which of the ICT resources listed below are available for use at school for educator and whether you have made use of them

\begin{tabular}{l}
\hline ICT Resource \\
\hline Is it available? If so, have you used it? \\
Personal email account \\
School intranet \\
Internet \\
Printer \\
Digital cameras \\
Technical support \\
Digital projectors/interactive whiteboards \\
Desktop computers for student use in your Classroom \\
Desktop computers for student use elsewhere \\
at school (eg. computer lab) \\
Laptop computers for student use
\end{tabular}

2. Access to Professional Development

Please indicate whether you have undertaken professional development in any of the ICT areas listed below? If so, please also indicate whether the professional development was arranged through your school and if you found it to be effective? 


\begin{tabular}{|c|c|c|c|}
\hline Professional Development & $\begin{array}{c}\text { Have you } \\
\text { undertaken it? }\end{array}$ & $\begin{array}{l}\text { If so, was it arranged } \\
\text { through your school? }\end{array}$ & Have you applied it \\
\hline $\begin{array}{l}\text { Training in the use of computers/basic } \\
\text { computer }\end{array}$ & & & \\
\hline Word processing (eg. MSWord) & & & \\
\hline Spread sheets (eg. Excel) & & & \\
\hline $\begin{array}{l}\text { Training on how to integrate technology } \\
\text { within Your discipline } \\
\text { student information systems (SIS) } \\
\text { Curriculum Manager-(Record lesson } \\
\text { attendance, Locate student records, } \\
\text { Create a plan, Generate student reports } \\
\text { or Analyse student data) }\end{array}$ & & & \\
\hline
\end{tabular}

3. Please describe any factors that hinder your desire to use of ICT in the classroom?

4. Please describe any factors that would increase your use of ICT in the classroom?

Thanking you in advance

\section{Programme Evaluation Questionnaire}

\section{Questionnaire: Outcomes of Programme}

The CIECT team is kindly requesting all educator-participants to complete the following questionnaire. The questionnaire is part of the CIECT's monitoring and evaluation of the workshop. The information you will provide will be treated with seriousness, and also with confidentiality.

Name:

What is your teaching discipline (Primary, High School, Level) and course subject:

1. How many hours were you able to engage with the "online activities"?
A. 2 - 4 hours a week
B. 5 - 7 hours a week
C. 8 or more hours a week

2. What were the main factors that impacted your interactive participation?

3. How important was the face-to-face phases of the programme. Do you think it is necessary to have face-to-face interaction?

A. Very important.

B. Not that important.

4. What eTools will you make use of to enhance your teaching practice and why?

5. Do you have any suggestions/comments on the overall structure and facilitation of the programme? 
Scientific Research Publishing (SCIRP) is one of the largest Open Access journal publishers. It is currently publishing more than 200 open access, online, peer-reviewed journals covering a wide range of academic disciplines. SCIRP serves the worldwide academic communities and contributes to the progress and application of science with its publication.

Other selected journals from SCIRP are listed as below. Submit your manuscript to us via either submit@scirp.org or Online Submission Portal.
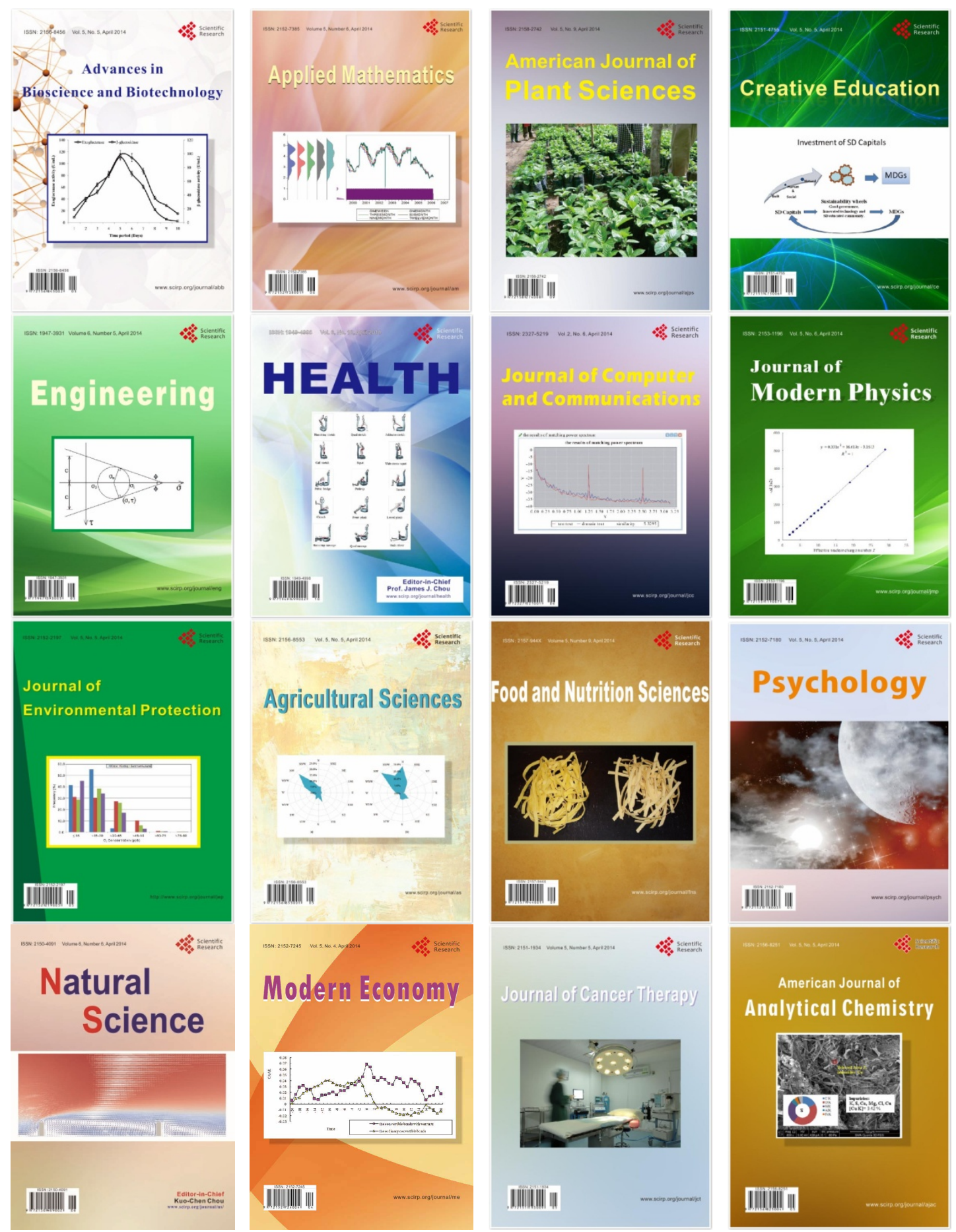